time or another by the privileges enjoyed by junior office-workers in comparison with those accorded to tried servants of the company "on the clock".

An analogous position is to-day to be found in most drawing offices. At the top are skilled mechanical designers, mostly in their late fifties or sixties; but where are their successors? The men who should be following them started as apprentices in the shops, took the first opportunity to get out of the shops into the drawing office, and then proceeded by dint of hard work to qualify as associate members of one of the Institutions ; this opened the door to 'design', sales and all the other apparently more lucrative and socially more attractive avenues in the company. Until the importance and the difficulty of first-class mechanical design-work on the drawing board is recognized in terms of both salary and status, the situation can only continue to decline, while professional engineers and scientific workers become ever more frustrated at the lack of men able to translate their basic concepts into hardware without constant supervision.

The old methods of training craftsmen both in the shops and drawing office depended essentially on time. During the War the Ministry of Labour training centres, making use of the work of Sir Frederic Bartlett, showed that by modern methods of selection and training a degree of skill could be attained by men and women in times that make nonsense of the old conception of the five-year apprenticeship. One looks forward to the day when it will be possible to review a presidential address describing the success of a large firm in applying scientific methods to the selection and training of its men.

D. B. WELBOURN

\section{FORECASTING WEATHER FROM SOLAR RADIATION}

$\mathrm{M}$ ORE than seventy years ago Dr. S. P. Langley began measurements of the solar radiation and its spectrum. By 1902 his results had led him to the belief that the so-called 'solar constant' was in fact a variable, and that its variations might be an important factor in terrestrial weather. In 1905 the research was taken up by C. G. Abbot, who has continued it ever since with single-minded devotion. In the second of the two papers here under consideration*, he sums up his conclusions, in an endeavour to persuade meteorologists to abandon their general scepticism or lack of interest, and at least to give him a fair hearing.

There are several reasons for this scepticism. Measurements of the solar constant have to be made through the atmosphere, and even on high mountains a proportion of it fails to reach the ground. In theory it is possible to estimate the loss by making a series of observations at different solar elevations, but in practice the complex structure of the upper atmosphere makes the results somewhat uncertain, and many meteorologists remain unconvinced that the observed variations are not, in reality, variations of atmospheric absorption. Some even regard the average computed value of the solar constant as too * Smithsonian Miscellaneous Collection: 122, No. 1, Long-Range
Effects of the Sun's Variation on the Temperature of Washington, D.C. (pp. 14; Pub. 4131); 122, No. 4, Solar Radiation, a Leading Weather Element (pp. 35; ; Pub. 4135) Both by C. G. Abbot. low by an amount much larger than the observed variations. Agreement between values obtained in widely different parts of the world has done some. thing to meet this objection, though it is probable that many of the disturbing factors, in the higher layers, are world-wide in extent. But even granted that the solar constant does vary, the variations found by Dr. Abbot are so small-only one or two per cent-that their direct effect on surface temperatures would be barely perceptible. Dr. Abbot counters this by the argument that the terrestrial effects are indirect, associated with changes in the location of the sub-tropical anti-cyclones and prevailing storm-tracks, and the frequency of hurricanes, all of which affect temperature and rainfall.

There is, of course, no doubt that changes do occur on the surface of the sun, and that some of them are more or less periodic-the existence of the sunspot cycle and of solar faculæ is sufficient evidence -and it is reasonable to accept that, along with variations of other types of radiation, such as corpuscular, ultra-violet and radio wave-lengths, they give rise to variations of visible and infra-red solar radiation. But Abbot goes far beyond this by claiming that these variations are strictly periodic, and that they are all harmonics of the double sunspot cycle of $22 \frac{3}{4}$ years. He enumerates at least twentythree such harmonics, ranging from $2 \frac{1}{7}$ months to 272 months. The amplitudes obtained are mostly microscopic, of the order of 0.1 per cent.

Such a complex array would require a rigid mathematical basis to justify its acceptance; but the method by which it is arrived at is crude and can scarcely be described as mathematical at all. From the description, it consists of plotting the data on a long curve, regarding it from a distance, and picking out the dominant periodicity by eye. This is then computed arithmetically and eliminated, the process being repeated until only non-periodic variations are left. Anyone who has worked with periodicities will realize the pitfalls of this graphical analysis, for the eye of faith only too readily sees regularities in the most irregular of curves. The process is bolstered up by dividing the material into sections; but to the critical eye the agreement between the different sections is not very good.

When we turn to the effect of these supposed variations of the solar constant on weather, the impression received is equally dubious. Dr. Abbot himself writes: "it would be quite impossible for meteorologists to discover these regular periodicities iu weather elements had they not first been found in solar variation". The italics are his ; but it is difficult to see how this argument helps his case. In support, he produces a number of curves illustrating various solar periodicities in the temperature of Washington and the precipitation of Albany, for various seasons and intervals, for high and low sunspot numbers. Some of the series seem chaotic, but some do show an appreciable resemblance, which is enhanced by introducing rather arbitrary shifts of the time scale.

However, one must be fair. No matter how crude Dr. Abbot's methods may appear to a statistician, he has the courage of his convictions. In the first paper he gives a closer study to the monthly temperatures at Washington. In the departures of 1854-1939 from monthly averages, he finds no fewer than twenty periodicities ranging from $4 \frac{1}{3}$ to $45 \frac{1}{2}$ months. These were used as the basis for 'predicting' the departures for $1940-51$, which were not used in the calculations 
of the periodicities. The results have a correlation of 0.504 with the observed values. From about thirty independent values (the figures are smoothed over five months) this makes a real connexion fairly probable (if it has not been introduced by the 'adjustments' of scale), but is far from justifying the claim that it is "obvious and certain". A further, real, forcast is given on the same basis for 1952-59, and it is interesting to compare the forecast temperatures with the observed as far as they are available (the observed temperatures have been supplied by the Meteorological Office, Harrow). Both forecast $\left(F^{\prime}\right)$ and observed $(O)$ temperatures are smoothed over five months.

\begin{tabular}{|c|c|c|c|c|c|c|c|}
\hline \multirow[t]{2}{*}{1952} & $\begin{array}{cc} & \text { Jan. } \\
F & 39 \cdot 1 \\
O & 42 \cdot 0\end{array}$ & $\begin{array}{l}\text { Feb. } \\
40 \cdot 4 \\
44 \cdot 6\end{array}$ & $\begin{array}{l}\text { Mar. } \\
47 \cdot 3 \\
49 \cdot 2\end{array}$ & & & $\begin{array}{l}\text { May } \\
66 \cdot 2 \\
64 \cdot 4\end{array}$ & $\begin{aligned} \text { June } & \\
72 \cdot 6 & \circ \\
71 \cdot 2 & \circ\end{aligned}$ \\
\hline & $\begin{array}{cc} & \text { July } \\
F & 75 \cdot 7 \\
O & 73 \cdot 6\end{array}$ & $\begin{array}{l}\text { Aug. } \\
73 \cdot 9 \\
72 \cdot 0\end{array}$ & $\begin{array}{l}\text { Sept. } \\
66 \cdot 2 \\
66 \cdot 2\end{array}$ & & & $\begin{array}{l}\text { Nov. } \\
44 \cdot 2 \\
50 \cdot 6\end{array}$ & $\begin{array}{l}\text { Dec. } \\
35 \cdot 2^{\circ} \mathrm{F} \text {. } \\
45 \cdot 2{ }^{\circ} \mathrm{F} \text {. }\end{array}$ \\
\hline & $\begin{array}{l}\mathrm{Jan} \\
35 \cdot 3 \\
43 \cdot 6\end{array}$ & $\begin{array}{l}\text { Feb. } \\
35 \cdot 9 \\
45 \cdot 2\end{array}$ & $\begin{array}{l}\text { Mar. } \\
43 \cdot 1 \\
51 \cdot 4\end{array}$ & $\begin{array}{l}\text { April } \\
54 \cdot 2 \\
58 \cdot 2\end{array}$ & $\begin{array}{l}\text { May } \\
63 \cdot 7 \\
65 \cdot 8\end{array}$ & $\begin{array}{l}\text { June } \\
72 \cdot 4 \\
71 \cdot 4\end{array}$ & $\begin{array}{l}\text { July } \\
78 \cdot 9 \\
74 \cdot 2\end{array}$ \\
\hline
\end{tabular}

Considering the extensive smoothing, while an error of less than $3^{\circ} \mathrm{F}$. might be regarded as a good forecast, more than $3^{\circ} \mathrm{F}$. would be poor, and more than $5^{\circ} \mathrm{F}$. bad. The forecast temperatures are reasonably accurate for the first ten months of 1952 and for May and June 1953, but from November 1952 to March 1953 and July 1953 they fail badly. Twelve good against six bad forecasts suggest that, while there may be some basis for Dr. Abbot's predictions, it is far from sound, and certainly does not justify the issue of a forecast.

$$
\text { C. E. P. Brookg }
$$

\section{FEDERAL FOREST ADMINISTRATION IN MALAYA}

\section{ANNUAL REPORT FOR 1951}

$\mathrm{T}$ $\mathrm{HE}$ annual forest reports of the Federation of Malaya for 1949 and 1950 gave testimony to the remarkable progress being made by the Forest Department in spite of the Japanese occupation during the Second World War and the present-day troubles (see Nature, 167, 679 (1951), and 169, 700 (1952)). The report for $1951^{*}$ by the director of forestry, Mr. J. P. Edwards, shows that the progress has been continued.

Further to this, however, the report is of historical interest in that, in an introduction on the history of the Malayan forests and their development, material of vital importance is recorded which has so often been lost in other countries in the past through failure of records. As early as 1883 a small department was set up in the Straits Settlement under the director of gardens. Four years later Mr. H. N. Ridley became director, and he carried out an extensive programme of reservation of valuable forests which would otherwise have been entirely destroyed during the 1910 rubber boom in Malacca ; reservation of forests on the higher hills in Penang was also effected. Control of the forests was assumed by the land officers in 1895 and continued until 1901. The forests of the former Federated Malay States had also been

* Report on Federal Forest Administration in the Federation of Malaya for the Year 1951. By J. P. Edwards. Pp. 67+4 plates
(Kuala Lumpur: Govt. Printer, 1952.) 2 Malay dollars or $48.8 d$. in charge of the district land officer in Perak, Selangor and Negri Sembilan.

The introduction of an up-to-date forest conservancy resulted from a visit of a distinguished Indian forest officer, Mr. H. C. Hill (later inspectorgeneral of forests in India), in 1900, who submitted a comprehensive report on forest administration in the Colony. This was followed by the appointment in October 1901 of Mr. A. M. Burn-Murdoch (from the Burma Forest Department) as the first chief forest officer, Federated Malay States and Straits Settlements. Burn-Murdoch laid the foundations of the Department as it is to-day. The Department has been fortunate in having had several first-class successors to carry on the work so effectually. Forest research was started with the appointment in 1918 of the late Dr. F. W. Foxworthy as forest research officer. Not only did Foxworthy place the branch in a strong position which has since been added to (including recently a new up-to-date laboratory for research on wood anatomy, mensuration and timber); but his work also became widely known in other parts of the world. E. P. Sterbbing

\section{TERTIARY FLORAS}

$\mathrm{T}$ THE rich fossil flora of the well-known Middle Tertiary lake bed at Florissant, Colorado, some 8,500 ft. up in the Central Rocky Mountain regions, is notable for its very numerous species and for the excellent preservation of the plant impressions of twigs and leaves, with some fruits, seeds and flowers : there is also an abundant fauna, chiefly of insects. The general features of the flora are well known from earlier descriptions by Lesquereux, Cockerell, Knowlton and others. A recent monograph by Dr. MacGinitie*, in the finely produced series of the Carnegie Institution of Washington, gives a revised and extended account of the flora, with a full analysis of its relationships with other floras of the remarkable North American Tertiary series, and special interest is attached to the use of the Florissant plant popu. lation as a climatic indicator, and in dating the lake bed, the age of which has been uncertain.

A glance at the list of synonyms and changes of name indicates the wide extent of the taxonomic revision involved. From earlier accounts, some 258 species have been described; but this revision reduces the number of well-established species to 114. Of these, 110 are species of seed plants (mostly trees and shrubs) representing 84 genera from 44 families, and 20 new species are included. The most abundant plant in the flora is Fagopsis longifolia, belonging to an extinct genus which so far as is known is peculiar to Florissant: this genus has previously been included in the Fagaceae, but is now referred by MacGinitie to the Betulaceæ on the evidence of the attached "cones". Among other abundantly represented species are Zelkova drymeja, Chamaecyparis linguaefolia, Typha lesquereuxi, Populus crassa, Sequoia affinis, Cercocarpus myricaefolius and Athyana haydenii. Using the fossil species the relationships of which with modern species are reasonably clear, a comparison is made with living floras : and the picture of the Florissant flora which emerges is one of predominantly warm temperate

- Carnegie Institution of Washington. Contributions to Paleontology. Fossil Plants of the Florissant Beds, Colorado. By Harry D. MacGinitle. Pp. iii $+198+75$ plates. (Publication No. 599.) (Washington, cloth, 5.75 dollars. 